Sains Malaysiana 49(9)(2020): 2119-2127

http://dx.doi.org/10.17576/jsm-2020-4909-10

\title{
Nitrogen Optimization on Rhamnolipid Biosurfactant Production from Pseudoxanthomonas sp. G3 and Its Preservation Techniques
}

(Pengoptimuman Nitrogen pada Pengeluaran Biosurfaktan Rhamnolipid daripada Pseudoxanthomonas sp. G3 dan Teknik Pemeliharaannya)

\author{
Isty Adhitya Purwasena, Dea Indriani Astuti* \& Salsabila Ghina Utami
}

\begin{abstract}
Biosurfactant is a microbial bioproduct that is used to reduce the surface tension, and can acted as emulsifier, dispersant, and anti-adhesive. Optimization of biosurfactant production needs to be done, not only to increase its production quantity, but also to reduce overall production cost. This study aims to determine the most suitable and optimum concentration of nitrogen source for biosurfactant production and its preservation techniques. The biosurfactant was produced by Pseudoxanthomonas $s p$. G3 using minimal salt medium with 2\% light crude oil as carbon source and different nitrogen sources in the form of urea, sodium nitrate, and ammonium nitrate. The activity of biosurfactants were measured by emulsification index (E24), interfacial tense (IFT), oil drop assay, and dry weight. Potassium sorbate $0.2 \%(w / v)$ was used as preservative agent. The results showed that biosurfactant production using sodium nitrate as a nitrogen source provides the highest activity and yield. The E24 value was $76.63 \%$ and the clear zone diameter observed was $0.875 \mathrm{~cm}$. The overall decreased in IFT was $35.4 \%$ and the biosurfactant dry weight was $0.45 \mathrm{gL}^{-1}$. Microbial contamination occurred after 3 weeks of storage in the treatment without the addition of preservative. It also showed that the activity of biosurfactants (emulsification and IFT) were gradually decreased during storage. In conclusion, the optimum biosurfactant production by Pseudoxanthomonas sp. G3 was obtained by the addition of sodium nitrate $0.3 \%(w / v)$. Meanwhile, the most effective biosurfactant preservation method was by adding potassium sorbate which was stored at $4{ }^{\circ} \mathrm{C}$.
\end{abstract}

Keywords: Biosurfactant; nitrogen; pottasium sorbate; preservation; Pseudoxanthomonas sp.

ABSTRAK

Biosurfaktan adalah bioproduk mikrob yang digunakan untuk mengurangkan ketegangan permukaan dan boleh bertindak sebagai pengemulsi, penyerak dan anti-pelekat. Pengoptimuman pengeluaran biosurfaktan perlu dilakukan bukan hanya untuk meningkatkan kuantiti pengeluarannya, tetapi juga untuk mengurangkan keseluruhan kos pengeluaran. Kajian ini bertujuan untuk menentukan kepekatan sumber nitrogen yang paling sesuai dan optimum untuk pengeluaran biosurfaktan dan teknik pemeliharaannya. Biosurfaktan dihasilkan oleh Pseudoxanthomonas sp. G3 menggunakan medium garam minimum dengan 2\% minyak mentah ringan sebagai sumber karbon dan sumber nitrogen berbeza dalam bentuk urea, natrium nitrat, dan ammonium nitrat. Aktiviti biosurfaktan diukur dengan indeks pengemulsi (E24), tegangan antara muka (IFT), asai penurunan minyak dan berat kering. Kalim sorbat $0.2 \%(w / v)$ digunakan sebagai agen pengawet. Hasil kajian menunjukkan bahawa pengeluaran biosurfaktan menggunakan natrium nitrat sebagai sumber nitrogen memberikan aktiviti dan hasil tertinggi. Nilai E24 adalah $76.63 \%$ dan diameter zon jernih yang diperhatikan ialah $0.875 \mathrm{~cm}$. Keseluruhan penurunan IFT adalah $35.4 \%$ dan berat kering biosurfaktan adalah $0.45 \mathrm{gL}^{-1}$. Pencemaran mikrob berlaku selepas penyimpanan selama 3 minggu dalam rawatan tanpa penambahan bahan pengawet. Ini juga menunjukkan bahawa aktiviti biosurfaktan (pengemulsi dan IFT) secara beransur-ansur berkurang semasa penyimpanan. Kesimpulannya, pengeluaran biosurfaktan optimum oleh Pseudoxanthomonas sp. G3 diperoleh dengan penambahan natrium nitrat $0.3 \%(w / v)$. Sementara itu, kaedah pengawetan biosurfaktan yang paling berkesan adalah dengan menambahkan kalium sorbat yang disimpan pada suhu $4^{\circ} \mathrm{C}$.

Kata kunci: Biosurfaktan; kalium sorbat; nitrogen; pemeliharaan; Pseudoxanthomonas sp.

\section{INTRODUCTION}

Biosurfactant is an amphipathic compound which is composed by a hydrophilic region (water soluble) and a hydrophobic region (non-water soluble). Biosurfactants have several functions, such as emulsifier, reducing surface tension or interfacial tense, bioremediation agents, 
dispersing agents, and solvents (Purwasena et al. 2019; Santos et al. 2016). Biosurfactants have a smaller CMC value than synthetic surfactants and more environmentally friendly (Campos et al. 2013).

In 2013, the world's biosurfactant market reached $344,068.40$ tons and is expected to increase up to $461,991.67$ tons in 2020 (Singh et al. 2018). The household detergent and personal care industries are the largest market for biosurfactants (Anon. 2015). High demand for biosurfactants induced the need for utilizing economical raw materials as the precursor for biosurfactant production, hence the production cost can be suppressed. Considering the high cost of biosurfactants production, it is important to use proper storage methods, so that the maintenance costs can be reduced. It is reported that proper storage methods help to maintain the ability of biosurfactant activity (Freitas et al. 2016).

Optimization of biosurfactant production can be done by optimizing the source and amount of energy sources used by microorganisms, such as carbon and nitrogen sources. Different nitrogen sources can be used in the biosurfactant production, including complex and non-complex compounds (Roy 2017). One of the microorganisms that as the ability to produce biosurfactants is Pseudoxanthomonas sp. (Astuti et al. 2019). Biosurfactant type produced by Pseudoxanthomonas sp. is rhamnolipid which is a derivative of glycolipids. Glycolipids known for its function to reduce surface tension (Nayak et al. 2009).

This study aims to determine the most optimum type and concentration of nitrogen source in the biosurfactant production by Pseudoxanthomonas sp. G3. and determine the most effective biosurfactant preservation method.

\section{MATERIALS AND METHODS}

\section{MICROORGANISM}

Psedoxanthomonas sp. G3 used for biosurfactant production was isolated from a sample contained crude heavy oil from petroleum reservoir in South Sumatra. The strain was isolated through two sequential stages method using Stone Mineral Salt Solution (SMSS) medium with $0.1 \%(\mathrm{w} / \mathrm{v})$ yeast extract and incubated at $50{ }^{\circ} \mathrm{C}$ with 120 rpm agitation for 7 days (Astuti et al. 2019). The isolate was then deposited at ITB Culture Collection.

\section{BIOSURFACTANT PRODUCTION}

The biosurfactant production was carried out using SMSS medium containing: $\mathrm{MgSO}_{4} \cdot 7 \mathrm{H}_{2} \mathrm{O}\left(\mathrm{MW} 246.47 \mathrm{gmol}^{-1}\right.$ ) - $0.5 \mathrm{gL}^{-1}, \mathrm{MnCl}_{2} .4 \mathrm{H}_{2} \mathrm{O}$ (MW: $197.91 \mathrm{gmol}^{-1}$ ) - $0.2 \mathrm{gL}^{-1}$, $\mathrm{CaCO}_{3}$ (MW $100.087 \mathrm{gmol}^{-1}$ ) $0.5 \mathrm{gL}^{-1}, \mathrm{Na}_{2} \mathrm{HPO}_{4} .7 \mathrm{H}_{2} \mathrm{O}$ (MW $168.1 \mathrm{gmol}^{-1}$ ) - $1 \mathrm{gL}^{-1}$, and $\mathrm{KH}_{2} \mathrm{PO}_{4}$ (MW 136.086 $\mathrm{gmol}^{-1}-0.5 \mathrm{gL}^{-1}$. Trace element solution was also added to the medium, which is composed by: $\mathrm{FeSO}_{4} 7 \mathrm{H}_{2} \mathrm{O}$ (MW $\left.278.01 \mathrm{gmol}^{-1}\right)-0.1 \mathrm{gL}^{-1}, \mathrm{ZnSO}$.7 $\mathrm{H} \mathrm{O}\left(\mathrm{MW}_{2} 287.6 \mathrm{gmol}^{-1}\right)$ - $0.1 \mathrm{~g} \mathrm{~L}^{-1}, \mathrm{Na} \mathrm{MoO} \mathrm{:}\left(\mathrm{MW} 205.92 \mathrm{gmol}^{-1}\right)$ - $0.06 \mathrm{gL}^{-1}$, and $\mathrm{CuSO}_{4} \cdot 2 \mathrm{H}_{2} \mathrm{O}\left(\mathrm{MW} 195.639 \mathrm{gmol}^{-1}\right)-0.01 \mathrm{gL}^{-1}$ (Gudina et al. 2013). Light crude oil ( $2 \% \mathrm{v} / \mathrm{v})$ was used as carbon source. Nitrogen sources used in this study were urea, sodium nitrate, and ammonium nitrate (Singh \& Tiwary 2016). Culture was incubated in an Erlenmeyer flask at $50{ }^{\circ} \mathrm{C}$ on rotary shaker at $120 \mathrm{rpm}$ (IKA type KS501 Digital) for 3 days (Astuti et al. 2019).

\section{BACTERIA GROWTH CURVE AND BIOSURFACTANT PRODUCTION CURVE}

Growth and biosurfactant production curve were generated by inoculating Pseudoxanthomonas sp. G3 which was grown on minimal salt medium with light crude oil as carbon source. Sodium nitrate concentration was varied from, 0.3 to $1.2 \%(\mathrm{w} / \mathrm{v})$. Control was treated without the addition of sodium nitrate. Bacterial culture was incubated at $50^{\circ} \mathrm{C}, 120 \mathrm{rpm}$. Sampling was done every $12 \mathrm{~h}$ for 4 days. Growth curve was analyzed by calculating the total plate number through the spread method. Samples were spread on a sterile nutrient agar surface and incubated for $24 \mathrm{~h}$ in a $50{ }^{\circ} \mathrm{C}$ incubator. Biosurfactants harvesting was carried out to determine the patterns of biosurfactant production during the time of growth. Harvesting time was done at the same time as the sampling period when generating the growth curves. The biosurfactant production pattern was determined by measuring the biosurfactant dry weight obtained from the extraction.

\section{ISOLATION AND PURIFICATION OF BIOSURFACTANTS}

The culture medium was centrifuged at $7.500 \mathrm{~g}$ for 15 min (Eppendorf Centrifuge 5430). The resulting supernatant was filtered using No.1 Whatman paper to separate the supernatant from the oil and debris cell. Chloroform:Methanol $(2: 1 \mathrm{v} / \mathrm{v})$ was added to the supernatant. Organic phase from the addition of chloroform: methanol was taken out, which then transferred into a container for evaporating. The resulting dry weight is finally weighed (Smyth et al. 2010).

\section{PRESERVATION OF BIOSURFACTANTS}

Purified biosurfactants were dissolved using sterile demineralized water with a concentration of $0.3 \mathrm{gL}^{-1}$ and filtered by a $0.22 \mu \mathrm{m}$ membrane filter. Biosurfactants were stored in sterile glass bottles and preserved by three different methods: Without preservatives, with addition of $0.2 \%(\mathrm{w} / \mathrm{v})$ potassium sorbate, and by storing it in powder form. After each treatment, biosurfactants were stored at room temperature. Additionally, treatment without preservatives, and with addition of $0.2 \%(\mathrm{w} / \mathrm{v})$ potassium sorbate were also stored at $4{ }^{\circ} \mathrm{C}$ (Freitas et al. 2016 with modification). 
Preservation was carried out for 49 days, then activity and microbial assay were evaluated. Interfacial tense (IFT) assay and emulsification activity were observed on day 0,18 , and 49 , while microbial assay was done every 7 days to observe the growth of contaminating bacteria.

\section{BIOSURFACTANT EMULSIFICATION ACTIVITY}

Biosurfactant emulsification activity was performed by adding $2 \mathrm{~mL}$ of hydrocarbons into $2 \mathrm{~mL}$ of biosurfactant solution, which then vortexed for $2 \mathrm{~min}$. The calculation was conducted after $24 \mathrm{~h}$ with the emulsification index equation (1) as described in Walter et al. (2010):

$$
E 24=\frac{\text { Height of emulsified layer }}{\text { Total height }} \times 100 \%
$$

\section{INTERFACIAL TENSE ASSAY}

Interfacial tense assay was carried out using a Du-Nouy Fischer Surface Tensiomat Model 21 ring tensiometer with a ring diameter of $6 \mathrm{~cm}$ at $50{ }^{\circ} \mathrm{C}$ in the facility provided by the Physical-Chemistry Laboratory, Faculty of Mathematics and Natural Sciences, ITB.

\section{OIL SPREADING ASSAY}

Oil spreading assay was done by adding $20 \mu \mathrm{L}$ of oil into a petri dish filled with distilled water in order to form a thin layer of oil. About $10 \mu \mathrm{L}$ of biosurfactant was added to the center of the oil layer. Biosurfactant activity was observed when the oil layer moved and a clear layer was formed (Walter et al. 2010).

\section{RESULTS AND DISCUSSION}

\section{BIOSURFACTANT PRODUCTION USING DIFFERENT NITROGEN SOURCES}

The optimization of nitrogen sources was carried out by using three different nitrogen $(\mathrm{N})$ sources, such as urea, sodium nitrate, and ammonium nitrate with light crude oil as carbon source. In this study, control is the treatment without the addition of any nitrogen sources. To determine the optimum $\mathrm{N}$ source for biosurfactant production, four parameters were used: Emulsification index (E24), oil drop assay, interfacial tense, and dry weight of biosurfactant. The value of each parameter can be seen in Table 1.

Treatment with sodium nitrate produced the highest dry weight of biosurfactant, which was $0.45 \mathrm{gL}^{-1}$; while the lowest biosurfactant dry weight was resulted from the culture with ammonium nitrate as nitrogen source which was $0.38 \mathrm{gL}^{-1}$. Control treatment produced $0.043 \mathrm{gL}^{-1}$ dry weight of biosurfactant.
According to Sheng (2011), there is a correlation between biosurfactant concentrations and decreased surface tension. However, the significance value between the treatments without control showed $p>0.05$, indicating that there was no significant difference among the three different treatments.

A decreased level of surface tension occurred when biosurfactant accumulates at the interface between two insoluble liquids. Biosurfactant will reduce the repulsion between two different phases by forming micelles. Micelles allows the two phases to interact more easily (Pacwa-Płociniczak et al. 2011). Biosurfactants can form micelles optimally at a certain minimum concentrations called the critical micelle concentration (CMC). When approaching $\mathrm{CMC}$, the addition of biosurfactant will also increase the occurrence of micelle formation along with a decrease in surface tension. After reaching CMC, surface tension will remain or tend to be stable (Sheng 2011).

The addition of biosurfactants can cause a decrease in IFT value due to the formation of micelle. The lower interfacial tense, the better quality of a biosurfactant is (Sheng 2011). For IFT measurement, a cell-free supernatant was used. The oil evaluated in this analysis showed the IFT value of 35 dyne $\mathrm{cm}^{-1}$.

The highest decrease in IFT value was resulted from the biosurfactant with sodium nitrate as its nitrogen source. The IFT value was $22.6 \mathrm{dyne} \mathrm{cm}^{-1}$, which indicate a reduction of about $35.4 \%$. Meanwhile, the lowest decreased in IFT value was resulted from the biosurfactant with urea as its nitrogen source with the IFT value as low as 27.2 dyne $\mathrm{cm}^{-1}$ and a $22.3 \%$ reduction. The IFT value resulted from ammonium nitrate as nitrogen source was 24.98 dyne $\mathrm{cm}^{-1}$, with a reduction of about $28.6 \%$. For the control treatment, only $4.5 \%$ of reduction was observed.

Statistically, there are significant differences from each treatment $(p<0.05)$, which can be concluded that there is a correlation between the biosurfactant concentration with the decreased in surface tension. The highest biosurfactant concentration was produced from a nitrogen source in the form of sodium nitrate, while the lowest produced by control treatment.

In this analysis, $0.3 \mathrm{gL}^{-1}$ of biosurfactant, the concentration in which CMC (critical micellar concentration) of biosurfactant produced by Pseudoxanthomonas sp. G3 was used (Astuti et al. 2019). The largest diameter of oil drop was produced from biosurfactants with sodium nitrate as nitrogen source which was $0.875 \mathrm{~cm}$, while the smallest diameter produced by ammonium nitrate as nitrogen source which was $0.68 \mathrm{~cm}$. Based on the statistical analysis, there were no significant differences between treatments $(\mathrm{p}>0.05)$, but significant differences were found between treatments and control $(p<0.05)$. Biosurfactant has a function as dispersant, thus it caused oil to disperse and produce oil-drop zone. 
For the emulsification activity analysis, biosurfactants were used at the same concentration, which was $0.3 \mathrm{gL}^{-1}$ As shown in Figure 4, it can be seen that the highest emulsification index was produced by biosurfactants using urea as nitrogen source, which was $81.18 \%$. The emulsification index produced by sodium nitrate and ammonium nitrate as nitrogen source were 76.63 and $60.83 \%$, respectively. However, no significant difference was observed between treatments ( $\mathrm{p}>0.05)$.

Based on the emulsification analysis and oil drop assay, it can be concluded that the same biosurfactant concentration can produce different activities. Those differences can occur due to differences in biosurfactant side chain as a result from each treatment. Differences in side chain can affect the activity of biosurfactant (Desai \& Banat 1997).

Overall, it can be concluded that the use of sodium nitrate as nitrogen source can give the optimum amount and activity in the production of biosurfactant by Pseudoxanthomonas sp. G3 compared to other nitrogen sources used. The use of sodium nitrate also gave an optimal result in rhamnolipid production by Pseudomonas aeroginosa EM1 and Pseudomonas aeroginosa HR (Rashedi et al. 2006; Wu et al. 2008).

Nitrate assimilation proceeds slower than ammonium assimilation, which simulates the occurrence of nitrogen deficiency, where nitrate must be reduced to ammonium before it is consumed by cells. However, this process is rather advantageous for the production of rhamnolipid. Formation of biosurfactant depends on the glycolytic metabolic pathway. When nitrogen deficiency occurred, metabolism will tend to switch on the glycolytic pathway so that the process of biosurfactant formation can be initiated. When nitrogen is sufficient, the metabolism that mainly occurred is protein and DNA synthesis (Mulligan \& Gibbs 1989).

\section{GROWTH AND PRODUCTION CURVE USING DIFFERENT CONCENTRATION OF NITROGEN SOURCE}

Figure 1 shows that at $0-12 \mathrm{~h}$ of incubation, the cell growth was still in the lag phase. There was no significant change observed in the cell number which indicated that the cell was still in the adaptation to the new medium. The cells started to enter the log phase after $12-24 \mathrm{~h}$ of incubation at the treatment with the addition of $0.3,0.6$, and $1.2 \%$ $(\mathrm{w} / \mathrm{v})$ of nitrogen source. The culture showed the highest growth rate at the concentration of $0.3 \%(\mathrm{w} / \mathrm{v})$ compared to other treatments, while the highest cell number was reached at the concentration of $1.2 \%(\mathrm{w} / \mathrm{v})$ after $48 \mathrm{~h}$.

The growth curve of control treatment has decreased from the 12 to $84 \mathrm{~h}$. The initial cell number was $\log 7.47$ $\mathrm{CFU} \mathrm{mL}{ }^{-1}$, at the end it reached $\log 4.26 \mathrm{CFU} \mathrm{mL}^{-1}$. The decrease might be due to the absence of nitrogen sources, as it is an essential nutrient for microbe's growth (Madigan et al. 2006).

Each type of microorganism has a different optimal $\mathrm{CN}$ ratio value. Assuming the amount of $\mathrm{C}$ in each treatment is the same, the higher nitrogen concentration was used, and therefore the lower $\mathrm{CN}$ ratio would be. In a nitrogen deficiency state, growth rate would be slow. Nitrogen is an important component for DNA, RNA, and protein formation. However, when the amount of carbon is considered excessive by an organism, beside energy production, carbon can also be converted into biomass and used in cell division (Touratier et al. 1999).

Based on the biosurfactant production curve showed in Figure 2, it can be concluded that there was not not much difference observed between each treatment. The biosurfactant weight continued to increase during $0-72 \mathrm{~h}$ of incubation period. A decrease in biosurfactant production occurred after $72 \mathrm{~h}$ of incubation. The highest biosurfactant weight by $0.71 \mathrm{gL}^{-1}$ was resulted by supplementing $0.3 \%(\mathrm{w} / \mathrm{v})$ of sodium nitrate. Meanwhile, 0.6 and $1.2 \%(\mathrm{w} / \mathrm{v})$ of sodium nitrate produced 0.65 and $0.64 \mathrm{gL}^{-1}$ of biosurfactant after $72 \mathrm{~h}$ incubation. However, control treatment was still producing biosurfactant, but not significant as compared with other treatments. All treatment produced the highest production rate during $60-72 \mathrm{~h}$ of incubation. The biosurfactant production rate from $0.3,0.6$, and $1.2 \%$ concentration were $0.012,0.009$, and $0.0083 \mathrm{gh}^{-1}$, respectively.

Based on the cell growth and biosurfactant production rate, the addition of sodium nitrate at a concentration of $0.3 \%(\mathrm{w} / \mathrm{v})$ resulted the most optimum biosurfactant production compared to other concentration treatments.

Based on Figure 3, it can be observed that at a concentration of $0.3 \%(\mathrm{w} / \mathrm{v})$, cells entered the lag phase (adaptation) for $12 \mathrm{~h}$ and then continued with the log phase for $12-24 \mathrm{~h}$ incubation. After the first $24 \mathrm{~h}$, cells entered the stationary phase, which lasted until $48 \mathrm{~h}$. Over $48 \mathrm{~h}$ of incubation, there was a significant decreased in cells density which indicates that cells were entering the death phase.

Optimum biosurfactant production occurred from 12 until $72 \mathrm{~h}$, as the peak gradually declined over those periods. Optimum peak of cell growth and biosurfactant production occurred in different periods, when cells entered the stationary phase and started to decrease, but biosurfactant formation was still increased. It can be assumed that biosurfactant produced by Pseudoxanthomonas sp. G3 are secondary metabolites.

Biosurfactant can be formed in a growth-limiting condition. This mechanism is characterized by an increase in the amount of biosurfactant due to limitation of some components in the medium or decreased in the cell number. Biosurfactants are produced when there is limited $\mathrm{C} / \mathrm{N}$ ratio condition (Desai \& Banat 1997). 
Based on Figure 3, it can be observed that over time, cells number decreased in the control treatment. It might be due to the absence of nitrogen sources, as it is an essential nutrient for microbes to grow (Madigan et al. 2006). Nitrogen depletion caused reduction in biosurfactant production when compared with the treatments when used selected nitrogen sources.

\section{MICROBIAL AND BIOSURFACTANT STABILITY ASSAYS WITH DIFFERENT PRESERVATION METHODS}

The biosurfactants preservation was done by storing the biosurfactants in solid (powder) and liquid form. The biosurfactants preserved in liquid form are divided into four methods; preservation without preservative and preservation with pottasium sorbate as preservative. Each treatment was stored in room temperature and $4{ }^{\circ} \mathrm{C}$. In this case, preserving the biosurfactants in powder form was considered as control treatment, as biosurfactants are generally sold in powder form and dissolved in water when ready to use.

The preservative used in this study was pottasium sorbate, which is often used in the food and cosmetics industry due to its safety use for human and also affordable (Sofos et al. 1986). Potassium sorbate is one of antimicrobial compounds that works by inhibiting enzymes required for microbial growth. One of the reactions that inhibited by sorbate is respiration, where sorbate acts as a competitive inhibitor of acetate in the formation of acetyl-coA. Sorbate will bind to coenzyme A, which then inhibit other reactions associated with coenzyme A (Sofos \& Busta 1981).

The microbial growth in a product can lead to the degradation of certain substrates or ingredients. Substrate released from the product can be used as a source of nutrition by microbes. It reduced the stability of a product (Halla et al. 2018). The aim of $4{ }^{\circ} \mathrm{C}$ storage is to inhibit microbial growth (Madigan et al. 2006). Low temperature helped the inhibition of microbial growth by sabotaging the metabolism of microbes. Low temperatures can disrupt cell wall affinity, which affecting the substrate uptakes from the environment into the cell. When the temperature decreases, the cell membrane will become thicker with a decline in membrane fluidity, thus, at certain temperature it will change the phase into solid when the biological functions are lost (Nedwell 1999).

During preservation, observations were made based on three parameters; surface area, emulsification index, and microbial assay. The observation for microbial growth contamination was done once a week. As seen on Figure 4, during the storage for two weeks there has not been any contamination yet. But on the third week, contamination was observed in the non-preservative treatment at room temperature and $4{ }^{\circ} \mathrm{C}$, preservation with pottasium sorbate treatment at room temperature, and also on the controlled treatment (powder). However, treatment with added preservative at $4{ }^{\circ} \mathrm{C}$ showed contamination on the fifth week of storage.

Each treatments showed that the number of bacteria tends to increase every week; the highest number of bacteria was observed in the controlled treatment on the fifth week. Until the seventh week of storage, the treatment with added preservative that was stored in $4{ }^{\circ} \mathrm{C}$ had the lowest number of cell compared with the other treatments.

Contamination also occurred on the storage in the powder form which might be due to the increase of water activity. Increased water activity caused the microbial growth on the substrate (Peleg et al. 2015). Based on Fontana (2007), water activity less than 0.97 can inhibit microbial growth, such as E. coli, Pseudomonas fluorescence, and Clostridium sp. Staphylococcus aureus (aerob) bacteria was inhibited when water activity less than 0.86 . It was reported that no bacteria can grow in water activity less than 0.6 . Water activity in dry products in powder form, such as milk, coffee, and sugar ranges from 0.2 to 0.4 (Berk 2013).

Figure 5 shows that emulsification index from all treatments on the third week increased, which then decreased on week 7 . It showed that the biosurfactants storage still has the ability to form emulsions up to 7 weeks. As compared with the third week, stability was decreased on the seventh week. As explained by Halla et al. (2018), microbial growth can reduce the stability or ability of a product. Stability of a product can be reduced due to contaminating microbes that consumed the substrates, or the metabolism of contaminating microbes that interfere with the activity of the product (Rawat 2015).

The value of the surface tension measured at the beginning and at the end of storage is showed in Figure 6. Based on this figure, it can be observed that the surface tension value in non-preservative treatment both at room temperature and $4{ }^{\circ} \mathrm{C}$ temperature have increased. In the non-preservative treatment, the value of IFT arised from 23.3 to 33.74 dyne $\mathrm{cm}^{-1}$, whereas the value of IFT from the $4{ }^{\circ} \mathrm{C}$ treatment arised from 23.3 to 28.84 dyne $\mathrm{cm}^{-1}$.

As compared with other treatments, which is the preservation with potassium sorbate and the preservation in powder form, it can be observed that the value of IFT had a slight decrease which indicates the biosurfactant still has the ability to reduce the IFT value. This correlates with the growth of the contaminant microbes showed in Figure 4, where non-preservative treatment at room temperature and $4{ }^{\circ} \mathrm{C}$ had a higher contaminant bacterial cells compared with other treatments.

Overall, it can be assumed that the growth of the contaminating bacteria can reduce the biosurfactant activity in the formed emulsion and decreasing the surface tension. This can be minimized by using preservatives that act as an antimicrobial agent. Furthermore, preservation method by storing the biosurfactants in low temperature can inhibit the microbial growth. 
TABLE 1. The biosurfactant dry weight, interfacial tension (IFT), index emulsification (E24) and oil drop test from different nitrogen sources

\begin{tabular}{lcccc}
\hline Parameters & Control & Sodium nitrate & Ammonium nitrate & Urea \\
\hline Dry weight $\left(\mathrm{gL}^{-1}\right)$ & $0.0425 \pm 0.01$ & $0.4475 \pm 0.05$ & $0.38 \pm 0.03$ & $0.395 \pm 0.03$ \\
IFT $\left(\right.$ dyne $\left.\mathrm{cm}^{-1}\right)$ & $33.36 \pm 0.37$ & $22.6 \pm 0.31$ & $24.98 \pm 0.25$ & $27.2 \pm 0.46$ \\
E24 & $3.13 \pm 0.13$ & $76.63 \pm 1.23$ & $60.88 \pm 2.29$ & $81.18 \pm 1.66$ \\
Oil drop $(\mathrm{cm})$ & $0.26 \pm 0.17$ & $0.88 \pm 0.18$ & $0.68 \pm 0.09$ & $0.70 \pm 0.14$ \\
\hline
\end{tabular}

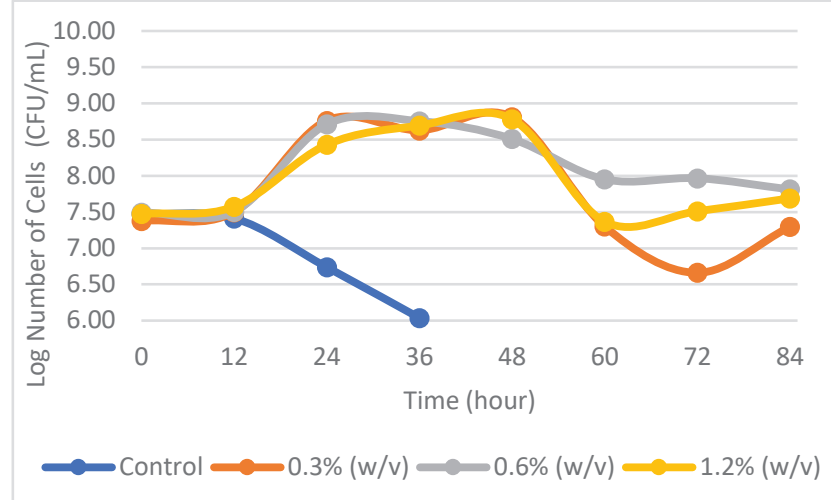

FIGURE 1. Growth curves of Pseudoxanthomonas sp. G3 with sodium nitrate concetration at $0.3,0.6$, and $1.2 \%(\mathrm{w} / \mathrm{v})$

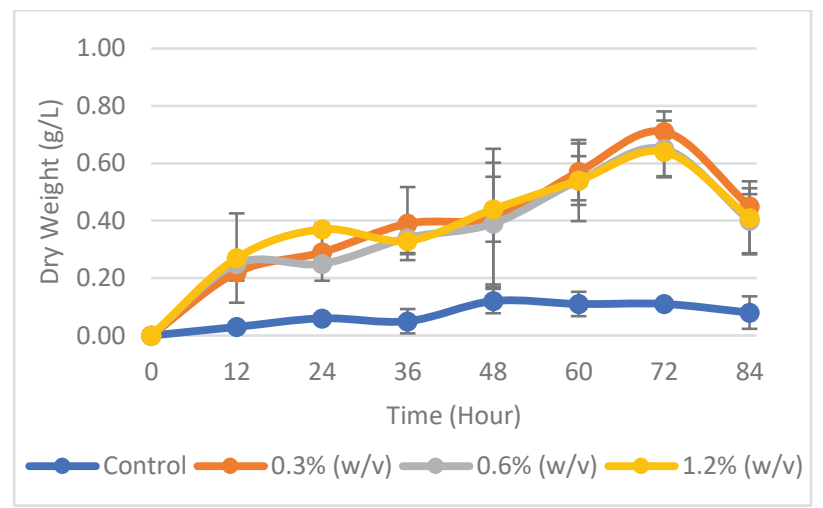

FIGURE 2. Production curve of Pseudoxanthomonas sp. G3 with sodium nitrate concetration at $0.3,0.6$, and $1.2 \%(\mathrm{w} / \mathrm{v})$ 


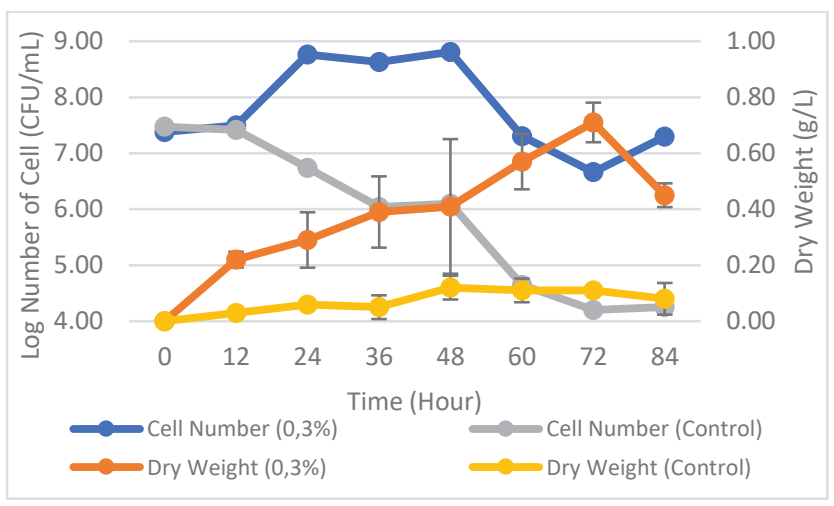

FIGURE 3. Growth and production curve comparison between $0.3 \%(\mathrm{w} / \mathrm{v})$ sodium nitrate and control

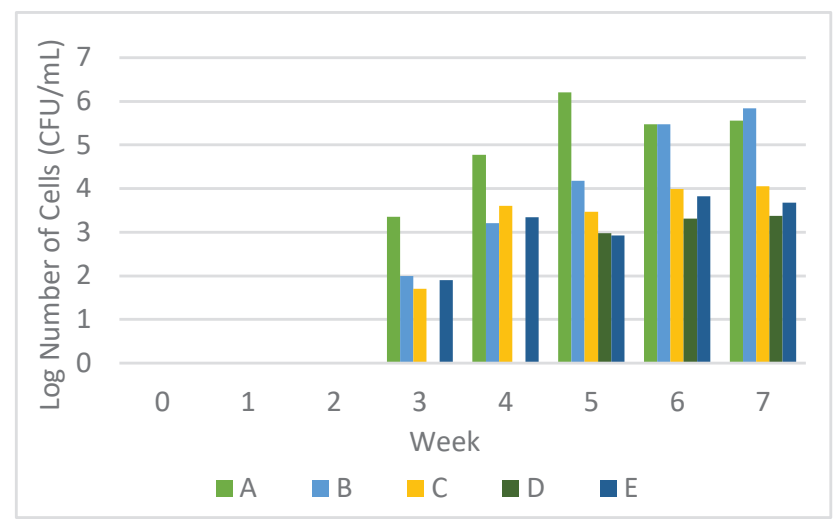

FIGURE 4. Bacterial growth contaminants of each preservation treatment for 7 weeks. A: Without preservatives (room temperature), B: Without preservatives (at $4{ }^{\circ} \mathrm{C}$ ), $\mathrm{C}$ : With the addition of preservatives (room temperature), D: With the addition of preservatives $\left(\right.$ at $4{ }^{\circ} \mathrm{C}$ ), and E: Powder

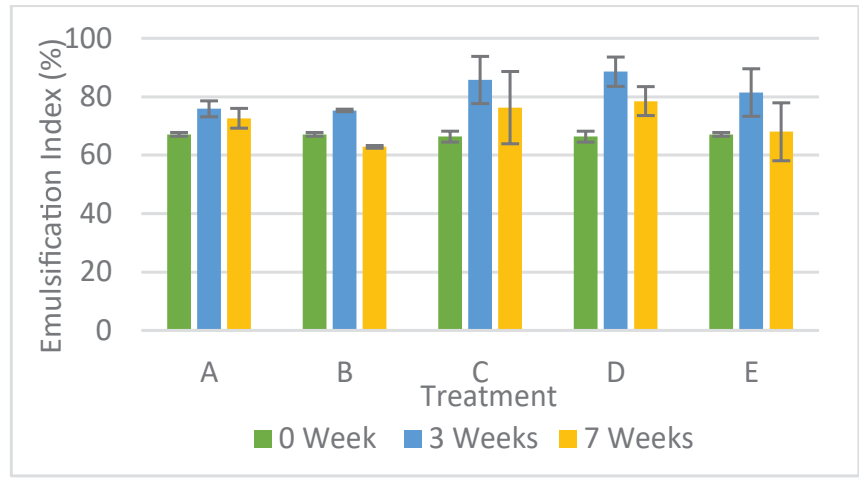

FIGURE 5. Emulsification index of each preservation treatment for 7 weeks. A: Without preservatives (room temperature), B: Without preservatives (at $4{ }^{\circ} \mathrm{C}$ ), C: With the addition of preservatives (room temperature), D: With the addition of preservatives (at $4{ }^{\circ} \mathrm{C}$ ), and E: Powder 


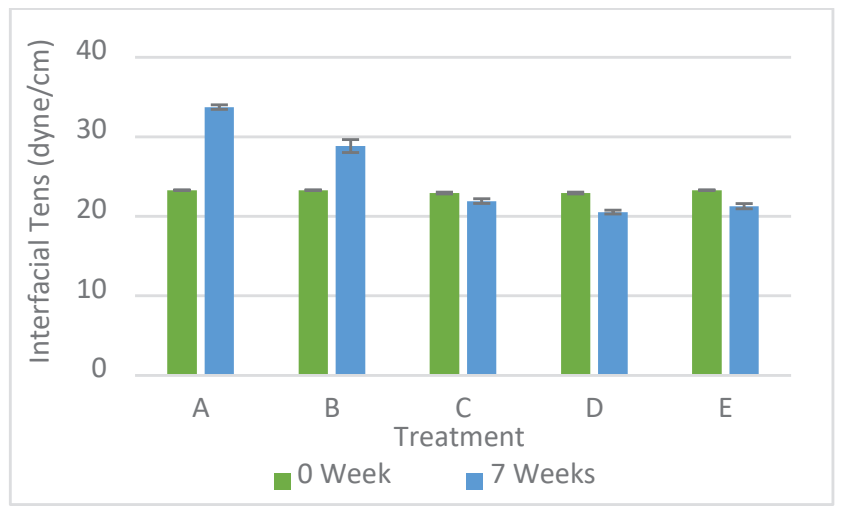

FIGURE 6. Interfacial tension of each preservation treatment at week- 0 and week- 7 th. A: Without preservatives (room temperature), B: Without preservatives (at $4{ }^{\circ} \mathrm{C}$ ), C: With the addition of preservatives (room temperature), D: With the addition of preservatives $\left(\right.$ at $4{ }^{\circ} \mathrm{C}$ ), and $\mathrm{E}$ : Powder

\section{CONCLUSION}

The optimum nitrogen source for biosurfactant production by Pseudoxanthomonas sp. G3 is $0.3 \%(\mathrm{w} / \mathrm{v})$ of sodium nitrate whereas the most effective biosurfactant preservation method is by supplementing potassium sorbate which then stored at $4{ }^{\circ} \mathrm{C}$.

\section{ACKNOWLEDGEMENTS}

The authors thank the Indonesian Ministry of Education, Directorate General of Higher Education (DIKTI) for facilitating and funding this study.

\section{REFERENCES}

Anon. 2015. Biosurfactants market analysis by product (Rhamnolipids, Sophorolipids, MES, APG, Sorbitan Esters, Sucrose Esters) and segment forecast. Grand View Research (GVR). 2014-2020. https://www.grandviewresearch.com/ industry-analysis/biosurfactants-industry.

Astuti, D.I., Purwasena, I.A., Putri, R.E., Amaniyah, M. \& Sugai, Y. 2019. Screening and characterization of biosurfactant produced by Pseudoxanthomonas sp. G3 and its applicability for enhanced oil recovery. Journal of Petroleum Exploration and Production Technology 9(3): 2279-2289.

Berk, Z. 2013. Physical Properties of Food Materials. Cambridge: Academic Press.

Campos, J.M., Stamford, T.L.M., Sarubbo, L.A., Luna, J.M., Rufino, R.D. \& Banat, I.M. 2013. Microbial biosurfactants as additives for food industries. Biotechnology Progress 29(5): 1097-1108.

Desai, J.D. \& Banat, I.M. 1997. Microbial production of surfactants and their commercial potential. Microbiology and Molecular Biology Reviews 61(1): 47-64.

Fontana Jr., A.J. 2007. Appendix D: Minimum water activity limits for growth of microorganisms. In Water Activity in Foods: Fundamentals and Applications, edited by Barbosa-
Canovas, G.V., Fontana Jr., A.J., Schmidt, S.J. \& Labuza, T.P. Oxford: Blackwell Publishing Ltd.

Freitas, B., Brito, J., Brasileiro, P., Rufino, R., Luna, J., Santos, V. \& Sarubbo, L. 2016. Formulation of a commercial biosurfactant for application as a dispersant of petroleum and by-products spilled in oceans. Frontiers in Microbiology 7: 1646-1654.

Gudina, E.J., Pereira, J.F.B., Costa, R., Coutinho, J.A.P., Teixeira, J.A. \& Rodrigues, L.R. 2013. Biosurfactant-producing and oil-degrading Bacillus subtilis strains enhanced oil recovery in laboratory sand-pack columns. Journal of Hazardous Materials 261: 106-113.

Halla, N., Fernandes, I., Heleno, S., Costa, P., Boucherit-Otmani, Z., Boucherit, K., Rodrigues, A., Ferreira, I. \& Barreiro, M. 2018. Cosmetics preservation: A review on present strategies. Molecules 23(7): 1571-1610.

Madigan, M.T., Martinko, J.M. \& Brock, T.D. 2006. Brock Biology of Microorganism. New Jersey: Pearson Prentice Hall.

Mulligan, C.N. \& Gibbs, B.F. 1989. Correlation of nitrogen metabolism with biosurfactant production by Pseudomonas aeruginosa. Applied and Environmental Microbiology 55(11): 3016-3019.

Nayak,A., Vijaykumar, M. \& Karegoudar, T. 2009. Characterization of biosurfactant produced by Pseudoxanthomonas sp. PNK04 and its application in bioremediation. International Biodeterioration \& Biodegradation 63(1): 73-79.

Nedwell, D.B. 1999. Effect of low temperature on microbial growth: Lowered affinity for substrates limits growth at low temperature. FEMS Microbiology Ecology 30(2): 101-111.

Pacwa-Płociniczak, M., Płaza, G.A., Piotrowska-Seget, Z. \& Cameotra, S.S. 2011. Environmental applications of biosurfactants: Recent advances. International Journal of Molecular Sciences 12(1): 633-654.

Peleg, M., Corradini, M.G. \& Normand, M.D. 2015. On modeling the effect of water activity on microbial growth and mortality kinetics. In Water Stress in Biological, 
Chemical, Pharmaceutical and Food Systems. Food Engineering Series, edited by Gutiérrez-López, G., Alamilla-Beltrán, L., del PilarBuera, M., Welti-Chanes, J., Parada-Arias, E. \& Barbosa-Cánovas, G. New York: Springer.

Purwasena, I.A., Astuti, D.I., Syukron, M., Amaniyah, M. \& Sugai, Y. 2019. Stability test of biosurfactant produced by Bacillus licheniformis DS1 using experimental design and its application for MEOR. Journal of Petroleum Science and Engineering 183(2019): 106383-106391.

Rashedi, H., Assadi, M.M., Jamshidi, E. \& Bonakdarpour, B. 2006. Optimization of the production of biosurfactant by Pseudomonas aeruginosa HR isolated from an Iranian Southern oil well. Iranian Journal of Chemistry and Chemical Engineering 25(1): 25-30.

Rawat, S. 2015. Food Spoilage: Microorganism and their prevention. Asian Journal of Plant Science and Research 5(4): 47-56.

Roy, A. 2017. Review on the biosurfactants: Properties, types and its applications. Journal of Fundamentals of Renewable Energy Applications 8(1): 248-261.

Santos, D., Rufino, R., Luna, J., Santos, V. \& Sarubbo, L. 2016. Biosurfactants: Multifunctional biomolecules of the 21st century. International Journal of Molecular Sciences 17(3): 401-431.

Sofos, J.N. \& Busta, F.F. 1981. Antimicrobial activity of sorbate. Journal of Food Protection 44(8): 614-622.
Sofos, J.N., Pierson, M.D., Blocher, J.C. \& Busta, F.F. 1986. Mode of action of sorbic acid on bacterial cells and spores. International Journal of Food Microbiology 3(1): $1-17$.

Touratier, F., Legendre, L. \& Vezina, A. 1999. Model of bacteria growth influenced by substrate $\mathrm{C}: \mathrm{N}$ ratio and concentration. Aquatic Microbial Ecology 19(2): 105-118.

Walter, V., Syldatk, C. \& Hausmann, R. 2010. Screening concepts for the isolation of biosurfactant producing microorganisms. In Biosurfactants. Advances in Experimental Medicine and Biology, edited by Sen, R. New York: Springer.

Wu, J.Y., Yeh, K.L., Lu, W.B., Lin, C.L. \& Chang, J.S. 2008. Rhamnolipid production with indigenous Pseudomonas aeruginosa EM1 isolated from oil-contaminated site. Bioresource Technology 99(5): 1157-1164.

Department of Microbiology

School of Life Sciences and Technology

Institut Teknologi Bandung

Jalan Ganesha, No. 10, 40132, Bandung

Indonesia

*Corresponding author; email: dea@sith.itb.ac.id

Received: 16 January 2020

Accepted: 10 May 2020 